\title{
Peripartum fetal distress in diabetic women: a retrospective case-cohort study
}

\author{
B Castelijn ${ }^{1,2^{*}} \mathbb{D}$, KWP Hollander ${ }^{1}$, JF Hensbergen ${ }^{3}$, RG IJzerman ${ }^{3}$, AW Valkenburg-van den Berg ${ }^{2}$, JWR Twisk ${ }^{4}$, \\ CJM De Groot ${ }^{2}$ and MGAJ Wouters ${ }^{2}$
}

\begin{abstract}
Background: Major concerns of pregnancies complicated by diabetes mellitus are an increased risk of adverse perinatal outcome. The objective of this study was to analyse the rate of fetal distress during labor in women with type 1, type 2 and gestational diabetes compared to control women.

Methods: A retrospective case-cohort study was conducted at the VU University Medical Center, Amsterdam; a tertiary care hospital. 117 women with type 1 diabetes, 59 women with type 2 diabetes, 303 women with gestational diabetes and 15,260 control women were included, who delivered between March 2004 and February 2014. Linear and logistic regression analyses were used to compare maternal and pregnancy characteristics. Risk of fetal distress and perinatal asphyxia was assessed by multiple regression analyses, adjusted for confounding factors as age, smoking, parity, previous cesarean section, hypertensive disorder, pre-eclampsia, prematurity, induction of labor and macrosomia. Main outcome measure was fetal distress, defined either as clinical indication for instrumental or cesarean delivery; or low umbilical artery pH (UA pH), or admission to neonatal unit (NU).
\end{abstract}

Results: The indication for instrumental or cesarean delivery in women with type 1 and type 2 diabetes mellitus was more frequently based on fetal distress as compared to controls (adjusted OR $2.76 \mathrm{Cl} 1.74-4.40$ and adjusted OR $2.31 \mathrm{Cl}$ 1.19-4.51, respectively). In comparison with the control group, infants of women with type 1 diabetes had an increased risk of $\mathrm{UA} \mathrm{pH}<7.20$ (adjusted $\mathrm{OR} 1.88 \mathrm{Cl} 1.23-2.87$ ) or $\mathrm{UA} \mathrm{pH}<7.10$ (adjusted OR $3.35 \mathrm{Cl}$ 1.79-6.27). Also, infants of women with type 1 diabetes were at increased risk for admission to NU as compared to infants of control women (OR $8.07 \mathrm{Cl}$ 4.75-13.70).

Conclusions: Women with type 1 and type 2 diabetes are at increased risk of fetal distress during labor as compared to controls.

Keywords: Type 1 diabetes, Type 2 diabetes, Gestational diabetes, Fetal distress, Umbilical artery pH

\section{Background}

Diabetes mellitus is a common medical disorder characterized by an absolute or relative deficiency of insulin, thereby causing a chronic state of hyperglycemia. It is associated with an increased risk of atherosclerosis and an increased prevalence of cardiovascular diseases [1]. Type 1 diabetes mellitus is caused by a destruction of the $\beta$-cells of the islands of Langerhans in the pancreas, which produce insulin. Type 2 diabetes mellitus is

\footnotetext{
* Correspondence: castelijn_birgit@hotmail.com

'Department of Obstetrics and Gynecology, VU University Medical Center, PO Box 7057, Amsterdam 1007 MB, the Netherlands

2Department of Obstetrics and Gynecology, Onze Lieve Vrouwe Gasthuis, Amsterdam, the Netherlands

Full list of author information is available at the end of the article
}

characterized by insulin resistance and impairment in insulin secretion. Gestational diabetes mellitus is defined as carbohydrate intolerance with onset or first recognition during pregnancy [1].

It is estimated that $2-8 \%$ of pregnancies involve women with diabetes of which approximately $87.5 \%$ are gestational diabetes, of the remainder $7.5 \%$ are type 1 diabetes and $5 \%$ are type 2 diabetes [2-5]. In addition, there is a rising prevalence of pregnancies complicated by diabetes mellitus. This is due to a reduction in the maternal age at onset of diabetes and also that women are tending to delay reproduction [6]. Other factors that may contribute are an increasing prevalence of obesity,

(C) The Author(s). 2018 Open Access This article is distributed under the terms of the Creative Commons Attribution 4.0 International License (http://creativecommons.org/licenses/by/4.0/), which permits unrestricted use, distribution, and reproduction in any medium, provided you give appropriate credit to the original author(s) and the source, provide a link to the Creative Commons license, and indicate if changes were made. The Creative Commons Public Domain Dedication waiver (http://creativecommons.org/publicdomain/zero/1.0/) applies to the data made available in this article, unless otherwise stated. 
increased intake of polyunsaturated fat and decreased physical activity [7-9].

Pregnancies complicated by diabetes mellitus have an increased risk of maternal mortality and morbidity [10]. Furthermore, there is an increased risk of adverse perinatal outcomes, including births defects, perinatal mortality and morbidity $[10,11]$. It is suggested that higher rates of cesarean section (CS) result from failure to progress of labor, due to fetal macrosomia [12]. Data suggest that stillbirth and perinatal mortality may be increased as much as 3 times in women with pregestational diabetes compared to the general population [13]. In women with gestational diabetes these results varies widely [13-15]. It is hypothesized that fetal hypoxia, fetal acidemia and alterations in maternal and fetal metabolism may contribute to poor fetal outcome [16]. Therefore, the objective of this study is to evaluate the rate of intrapartum fetal distress in women with diabetes.

\section{Methods}

\section{Study population}

This retrospective case-cohort study was conducted at the VU University Medical Center, a tertiary care hospital in Amsterdam (The Netherlands) between March 2004 and February 2014. At the outpatient department, pregnant women with diabetes mellitus are monitored in accordance to a standardized evidence-based protocol by a multidisciplinary team consisting of a gynecologist, endocrinologist, diabetic nurse and a dietician [17].

Diabetes mellitus was classified in 3 different categories: type 1 diabetes, type 2 diabetes and gestational diabetes. The diagnosis of type 1 and type 2 diabetes was made prior to pregnancy in accordance to the Dutch guideline of internal medicine [18]. Pregnant women with one or more risk factors for gestational diabetes were screened and identified in accordance to the Dutch guideline of diabetes in pregnancy [17]. Risk factors for gestational diabetes included a history of gestational diabetes, macrosomia or unexplained intrauterine fetal death, BMI $>30 \mathrm{~kg} / \mathrm{m}^{2}$, family history of type 2 diabetes (first-degree relatives), ethnic origin (South-Asian, African-Caribbean, Moroccan, Egyptian and Middle Eastern), polyhydramnios, estimated fetal weight $>$ p95 and polycystic ovary syndrome. Screening for gestational diabetes was done by a 75-g oral glucose tolerance test. The diagnosis of gestational diabetes was based on a fasting plasma glucose level of $\geq 6.1 \mathrm{mmol} / \mathrm{L}$ or a 2 -h level $\geq 7.8 \mathrm{mmol} / \mathrm{L}[19]$.

During pregnancy, type 1 and type 2 diabetes were treated with insulin. Insulin Aspart (Novorapid ${ }^{\circ}$ ) and Insulin Isofane (Insulatard ${ }^{\circ}$ ) were most commonly prescribed. Gestational diabetes was initially treated with diet and lifestyle recommendations. If this resulted in insufficient glycemic control, insulin was prescribed.
Measurements of blood glucose levels were performed on clinical assessment. Measurements of $\mathrm{HbA}_{1 \mathrm{c}}$ levels were done every four to six weeks [17]. During follow-up visits, glycemic control was evaluated and insulin was started or adjusted if necessary. Highest $\mathrm{HbA}_{1 \mathrm{c}}$ levels in the third trimester were used for the purpose of this study and categorized in $<42 \mathrm{mmol} / \mathrm{mol}(<6 \%), 42-53 \mathrm{mmol} /$ $\mathrm{mol}(6-7 \%)$ and $>53 \mathrm{mmol} / \mathrm{mol}(>7 \%)$.

The study population included 479 pregnant women with diabetes mellitus and their infants. These women were matched to a control group that comprised 15,260 low to high risk women without diabetes who delivered at the VU University Medical Center over the same period of time. From 14 multiple-gestation pregnancies in women with diabetes mellitus and 647 multiple-gestation pregnancies in the control group, only first born infants were included in this study. This decision was based on the fact that the mode of delivery for the first born infant may directly influence the mode of delivery for the second born infant. In this respect, a randomized controlled trial by Barret et al. reported that in women planned for vaginal delivery for twin pregnancy already $7 \%$ underwent a cesarean section after their first born was delivered vaginally [20].

\section{Data collection}

Maternal characteristics (maternal age, hypertensive disorders, BMI, lifestyle), pregnancy characteristics (gravidity, nulliparity, gestational age at delivery, obstetric history of CS), mode of delivery, indication for instrumental delivery or CS and neonatal outcomes (Apgar-scores, umbilical artery (UA) $\mathrm{pH}$ and neonatal unit (NU) admission) were obtained from patient records and compared with those from the control group. Pre-existent hypertension, pregnancy-induced hypertension and pre-eclampsia were defined as hypertensive disorder. Birthweight above p95 or above $4500 \mathrm{~g}$ was defined as macrosomia [17]. Neonatal unit admission included all infants residing in the Neonatal Intensive Care Unit, High Care Unit or Neonatology ward.

Data regarding the control group was obtained from the Landelijke Verloskunde Registratie (LVR). The LVR is a national population-based surveillance system covering all births of $>16$ weeks gestation. It includes information on maternal characteristics, pregnancy, labor, delivery and neonatal outcomes.

The number and type of delivery of all women categorized as having diabetes were documented and compared with the control group. The indications for instrumental or cesarean delivery was analysed. Fetal distress was diagnosed by the clinician (gynecologist, resident, midwife) and was based on the fetus having a rapidly deteriorating or abnormal cardiotocographic (CTG) pattern and/or a fetal scalp $\mathrm{pH}<7.20$. After delivery, UA $\mathrm{pH}$ was 
determined to verify whether the clinical diagnosis of fetal distress was accurate. In accordance to the NICE guidelines, cut-off point of UA $\mathrm{pH}<7.20$ was defined as fetal distress [21]. Additional analysis was done using the cut-off point of UA $\mathrm{pH}<7.10$ due to its association with adverse neurological outcome [22].

\section{Statistical methods}

Linear and logistic regression analyses were used to compare maternal and pregnancy characteristics as well as neonatal outcome. Risk of fetal distress and perinatal asphyxia from type 1 , type 2 and gestational diabetes was determined by multiple regression analysis, adjusted for potential confounding factors such as age, smoking, parity, previous CS, hypertensive disorder, pre-eclampsia, prematurity, induction of labor and macrosomia. In additional analysis, the relation between $\mathrm{HbA}_{1 \mathrm{c}}$ levels and $\mathrm{UA} \mathrm{pH}$ was examined. Results are described in terms of odds ratios (OR), with 95\% confidence intervals (CI). All tests were two-sided and $p$ values $<0.05$ were considered statistically significant. Statistical analyses were performed with $\mathrm{SPSS}^{\circ}$ version 21 (IBM, Chicago, IL, USA).

\section{Results}

At the VU University Medical Center, 117 women with type 1 diabetes, 59 women with type 2 diabetes and 303 women with gestational diabetes were registered between March 2004 and February 2014.

Maternal and pregnancy characteristics are presented in Table 1. Our primary outcomes are summarized in in Tables 2, 3 and 4. Women with type 1 and type 2 diabetes were more likely to deliver by unplanned CS (type 1 diabetes $n=42,35.9 \%$, OR 3.92 CI; 2.55-6.03; type 2 diabetes $n=17,28.8 \%$, OR $3.03 \mathrm{CI} ; 1.61-5.72)$ than the control group $(n=2313,15.2 \%)$. In all types of diabetes, 84 women underwent an instrumental delivery due to suspected fetal distress (Table 2). Fetal scalp blood samples were obtained in 21 women, 6 of which showed a pH below 7.20. In these cases an instrumental delivery was performed due to low $\mathrm{pH}$. In all other cases $(\mathrm{pH} \geq 7.20)$, the final decision was based on the interpretation of the CTG.

Mean UA pH was slightly lower in women with type 1 diabetes $(7.22 \pm 0.09$, OR $-0.28 \mathrm{CI}$; - 0.04- -0.01) compared to the control group $(7.24 \pm 0.01)$. The risk of $\mathrm{UA} \mathrm{pH}<$ 7.20 or UA $\mathrm{pH}<7.10$ in type 1 diabetes compared with the control group was significantly increased (Table 4).

Table 1 Frequencies of maternal and pregnancy characteristics of women with diabetes mellitus and the control population

\begin{tabular}{|c|c|c|c|c|}
\hline Maternal and pregnancy characteristics & $\begin{array}{l}\text { Type } 1 \text { diabetes } \\
(n=117)\end{array}$ & $\begin{array}{l}\text { Type } 2 \text { diabetes } \\
(n=59)\end{array}$ & $\begin{array}{l}\text { Gestational diabetes } \\
(n=303)\end{array}$ & $\begin{array}{l}\text { Control group } \\
(n=15,260)\end{array}$ \\
\hline Age $[y$, mean $\pm S D]$ & $32.9 \pm 4.00$ & $35.9 \pm 4.86 * *$ & $35.5 \pm 4.98 * *$ & $\begin{array}{l}33.1 \pm 4.95 \\
(n=15,257)\end{array}$ \\
\hline Primigravidity [n (\%)] & $50(42.7)$ & $12(20.3) *$ & $80(26.4) * *$ & $6173(40.5)$ \\
\hline Nulliparity [n (\%)] & $61(52.1)$ & $17(28.8) * *$ & $\begin{array}{l}124(40.1) * * \\
(n=302)\end{array}$ & $\begin{array}{l}8131(53.4) \\
(n=15,216)\end{array}$ \\
\hline Previous CS [n (\%)] & $23(19.7) *$ & $22(37.3) * *$ & $47(15.5)$ & $1808(11.8)$ \\
\hline Smoker [n (\%)] & $\begin{array}{l}12(10.5) * \\
(n=114)\end{array}$ & $\begin{array}{l}2(3.5) \\
(n=57)\end{array}$ & $\begin{array}{l}19(6.8) \\
(n=280)\end{array}$ & $\begin{array}{l}592(5.0) \\
(n=11,873)\end{array}$ \\
\hline BMI $\left[\mathrm{kg} / \mathrm{m}^{2}\right.$, mean $\left.\pm \mathrm{SD}\right]$ & $\begin{array}{l}25.1 \pm 3.37 \\
(n=105)\end{array}$ & $\begin{array}{l}31.6 \pm 5.48 \\
(n=53)\end{array}$ & $\begin{array}{l}28.1 \pm 6.52 \\
(n=275)\end{array}$ & insufficient data \\
\hline \multicolumn{5}{|l|}{$\begin{array}{l}\mathrm{HbA}_{1 c}, \mathrm{mmol} / \mathrm{mol}(\%) \\
{[\mathrm{mean} \pm \mathrm{SD}]}\end{array}$} \\
\hline Trimester 1 & $\begin{array}{l}50 \pm 9.0 \\
(6.76 \pm 0.82)(n=95)\end{array}$ & $\begin{array}{l}51 \pm 12.6 \\
(6.81 \pm 1.15) \\
(n=38)\end{array}$ & $\begin{array}{l}38 \pm 5.9 * * * \\
(5.67 \pm 0.54) \\
(n=24)\end{array}$ & not available \\
\hline Trimester 2 & $\begin{array}{l}40 \pm 7.3 \\
(6.35 \pm 0.67)(n=112)\end{array}$ & $\begin{array}{l}47 \pm 11.1 \\
(6.42 \pm 1.02)(n=54)\end{array}$ & $\begin{array}{l}39 \pm 8.4 * * * \\
(5.72 \pm 0.77) \\
(n=96)\end{array}$ & not available \\
\hline Trimester 3 & $\begin{array}{l}48 \pm 9.5 \\
(6.54 \pm 0.87) \\
(n=111)\end{array}$ & $\begin{array}{l}47 \pm 9.1 \\
(6.42 \pm 0.83) \\
(n=53)\end{array}$ & $\begin{array}{l}40 \pm 6.3 * * * \\
(5.81 \pm 0.58) \\
(n=268)\end{array}$ & not available \\
\hline Hypertensive disorder [n (\%)] & $\begin{array}{l}47(40.9) * * \\
(n=115)\end{array}$ & $\begin{array}{l}30(51.7) * * \\
(n=58)\end{array}$ & $\begin{array}{l}83(28.9)^{* *} \\
(n=287)\end{array}$ & $1378(9.0)$ \\
\hline Pre-eclampsia [n (\%)] & $\begin{array}{l}13(11.3) * * \\
(n=115)\end{array}$ & $\begin{array}{l}6(10.3) * * \\
(n=58)\end{array}$ & $\begin{array}{l}26(9.1) * * \\
(n=287)\end{array}$ & $367(2.4)$ \\
\hline
\end{tabular}

Data are presented as mean \pm standard deviation or number (\%)

$*=p<0.01$ as compared to control group

$*^{* *}=p<0.001$ as compared to control group

$* * *=p<0.001$ as compared to type 1 diabetes 
Table 2 Frequencies of obstetric interventions and outcomes in women with diabetes mellitus and the control population

\begin{tabular}{|c|c|c|c|c|}
\hline Obstetric interventions and outcomes & $\begin{array}{l}\text { Type } 1 \text { diabetes } \\
(n=117)\end{array}$ & $\begin{array}{l}\text { Type } 2 \text { diabetes } \\
(n=59)\end{array}$ & $\begin{array}{l}\text { Gestational diabetes } \\
(n=303)\end{array}$ & $\begin{array}{l}\text { Control } \\
(n=15,260)\end{array}$ \\
\hline Induction [n (\%)] & $53(45.3) \neq$ & $25(42.4)+$ & $132(43.6) \neq$ & $\begin{array}{l}3515(23.0) \\
(n=15,255)\end{array}$ \\
\hline Preterm birth [n (\%)] & $31(26.5) *$ & $19(32.2)+$ & $37(12.2)+$ & $\begin{array}{l}2830(18.6) \\
(n=15,248)\end{array}$ \\
\hline \multicolumn{5}{|l|}{ Delivery mode [n (\%)] } \\
\hline Spontaneous $\S$ & $42(35.9) \S$ & $22(37.3) \S$ & $155(51.2) \S$ & $9072(59.4)$ \\
\hline VE/FE & $9(7.7)$ & $1(1.7)$ & $32(10.6)$ & $1796(11.8)$ \\
\hline Planned CS & $23(19.7) \neq$ & $19(32.2) \neq$ & $55(18.2)+$ & $1902(12.5)$ \\
\hline Unplanned CS & $42(35.9) \neq$ & $17(28.8)+$ & $58(19.1) *$ & $2313(15.2)$ \\
\hline Others & $1(0.9)$ & - & $3(1.0)$ & $177(1.2)$ \\
\hline \multicolumn{5}{|c|}{ Clinical indication for instrumental or cesarean delivery[n (\%)] } \\
\hline Failure to progress & 15 (12.9) & $3(5.2)$ & 41 (13.8) & 1991 (13.2) \\
\hline Fetal distress & $\begin{array}{l}32(27.6) \neq \\
(n=116)\end{array}$ & $\begin{array}{l}14(24.1)+ \\
(n=58)\end{array}$ & $\begin{array}{l}38(12.8) \\
(n=298)\end{array}$ & $\begin{array}{l}1655(11.0) \\
(n=15,078)\end{array}$ \\
\hline
\end{tabular}

Data are presented as mean \pm standard deviation or number (\%)

$\mathrm{VE}$, vacuum extraction; $\mathrm{FE}$, forceps extraction; Others, breach delivery or fundus expression

${ }^{*}=p<0.05$ as compared to control group

$\dagger=p<0.01$ as compared to control group

$\neq=p<0.001$ as compared to control group

$\S=$ referent variable of logistic regression analysis

$\mathrm{UA} \mathrm{pH}<7.20$ and $\mathrm{UA} \mathrm{pH}<7.10$ rates in type 1 diabetes were also increased compared to gestational diabetes, (adjusted OR $2.01 \mathrm{CI} ; 1.20-3.38$ and adjusted OR 2.64 CI; 1.13-6.21, respectively).

In addition, when fetal distress was the indication to instrumental delivery, higher rates of UA-pH $<7.20(n=17$; $56.7 \%)$ or UA-pH $<7.10(n=6 ; 20 \%)$ were found in women with type 1 diabetes as compared to the control group $(n=$ 531, 43.9\% adjusted OR 2.81 CI $1.10-7.20$ and $n=124$, $10.3 \%$ adjusted OR 4.47 CI 1.32-15.19 respectively).
In additional analysis, a significant relationship between maternal $\mathrm{HbA}_{1 \mathrm{c}}$ levels in the third trimester of pregnancy and neonatal UA pH was observed. Infants of women with $\mathrm{HbA}_{1 \mathrm{c}}$ levels $>53 \mathrm{mmol} / \mathrm{mol}$ were at increased risk of UA pH $<7.20(n=17,40.5 \%$, adjusted OR $2.49 \mathrm{CI} ; 1.12-5.54)$ compared to women with $\mathrm{HbA}_{1 \mathrm{c}}$ levels $<42 \mathrm{mmol} / \mathrm{mol}(n=40,21.2 \%)$. When comparing $\mathrm{UA} \mathrm{pH}<7.10$ in women with $\mathrm{HbA}_{1 \mathrm{c}}$ levels $>53 \mathrm{mmol} /$ $\mathrm{mol}$ and $<42 \mathrm{mmol} / \mathrm{mol}$ this risk was also increased $(n=$ $6,14.3 \%$ and $n=9,4.8 \%$ respectively, adjusted OR 3.94 CI;

Table 3 Frequencies of neonatal outcomes in women with diabetes mellitus and the control population

\begin{tabular}{|c|c|c|c|c|}
\hline Neonatal outcomes & $\begin{array}{l}\text { Type } 1 \text { diabetes } \\
(n=117)\end{array}$ & $\begin{array}{l}\text { Type } 2 \text { diabetes } \\
(n=59)\end{array}$ & $\begin{array}{l}\text { Gestational diabetes } \\
(n=303)\end{array}$ & $\begin{array}{l}\text { Control } \\
(n=15,260)\end{array}$ \\
\hline Birthweight $[g$, mean $\pm S D]$ & $3487.5 \pm 755.6+$ & $3345.5 \pm 936.4$ & $3443.2 \pm 702.1+$ & $\begin{array}{l}3102.1 \pm 975.6 \\
(n=15,243)\end{array}$ \\
\hline Macrosomia [n (\%)] & $45(38.5) \neq$ & $\begin{array}{l}19(32.8) \neq \\
(n=58)\end{array}$ & $60(19.8) \neq$ & $\begin{array}{l}695(4.8) \\
(n=14,518)\end{array}$ \\
\hline UA pH [mean \pm SD] & $\begin{array}{l}7.22 \pm 0.09+ \\
(n=104)\end{array}$ & $\begin{array}{l}7.23 \pm 0.08 \\
(n=51)\end{array}$ & $\begin{array}{l}7.24 \pm 0.08 \\
(n=247)\end{array}$ & $\begin{array}{l}7.24 \pm 0.08 \\
(n=8942)\end{array}$ \\
\hline UA pH $<7.20[n(\%)]$ & $\begin{array}{l}38(36.5)+ \\
(n=104)\end{array}$ & $\begin{array}{l}11(21.6) \\
(n=51)\end{array}$ & $\begin{array}{l}56(22.7) \\
(n=247)\end{array}$ & $\begin{array}{l}2186(24.4) \\
(n=8942)\end{array}$ \\
\hline $\mathrm{UA} \mathrm{pH}<7.10[\mathrm{n}(\%)]$ & $\begin{array}{l}13(12.5) \neq \\
(n=104)\end{array}$ & $\begin{array}{l}2(3.9) \\
(n=51)\end{array}$ & $\begin{array}{l}12(4.9) \\
(n=247)\end{array}$ & $\begin{array}{l}372(4.2) \\
(n=8942)\end{array}$ \\
\hline $\begin{array}{l}\text { Apgar (after } 5 \mathrm{~min})<7 \\
{[\mathrm{n}(\%)]}\end{array}$ & $\begin{array}{l}9(7.8) \\
(n=116)\end{array}$ & $\begin{array}{l}6(10.3) \\
(n=58)\end{array}$ & $\begin{array}{l}13(4.4)^{*} \\
(n=298)\end{array}$ & $\begin{array}{l}1263(8.3) \\
(n=15,246)\end{array}$ \\
\hline Admission to NU [n (\%)] & $\begin{array}{l}71(61.2) \neq \\
(n=116)\end{array}$ & $\begin{array}{l}27(45.8) \neq \\
(n=59)\end{array}$ & $\begin{array}{l}83(28.0) \neq \\
(n=296)\end{array}$ & $\begin{array}{l}2813(18.4) \\
(n=15,257)\end{array}$ \\
\hline
\end{tabular}

Data are presented as mean \pm standard deviation or number (\%)

$*=p<0.05$ as compared to control group

$\dagger=p<0.01$ as compared to control group

$\neq=p<0.001$ as compared to control group 
Table 4 OR of primary outcomes of women with diabetes as compared to the control population

\begin{tabular}{|c|c|c|c|c|c|c|}
\hline & \multicolumn{2}{|l|}{ Type 1 diabetes } & \multicolumn{2}{|l|}{ Type 2 diabetes } & \multicolumn{2}{|c|}{ Gestational diabetes } \\
\hline & $\begin{array}{l}\text { Crude OR } \\
(95 \% \mathrm{Cl})\end{array}$ & $\begin{array}{l}\text { Adjusted OR* } \\
(95 \% \mathrm{Cl})\end{array}$ & $\begin{array}{l}\text { Crude OR } \\
(95 \% \mathrm{Cl})\end{array}$ & $\begin{array}{l}\text { Adjusted OR* } \\
(95 \% \mathrm{Cl})\end{array}$ & $\begin{array}{l}\text { Crude OR } \\
(95 \% \mathrm{Cl})\end{array}$ & $\begin{array}{l}\text { Adjusted OR* } \\
(95 \% \mathrm{Cl})\end{array}$ \\
\hline \multicolumn{7}{|c|}{ Clinical indication for instrumental delivery or CS } \\
\hline - Failure to progress & $1.25(0.71,2.19)$ & $1.03(0.56,1.90)$ & $0.42(0.13,1.36)$ & $0.46(0.13,1.59)$ & $1.08(0.77,1.51)$ & $0.95(0.64,1.39)$ \\
\hline - Fetal distress & $3.20(2.10,4.89)$ & $2.76(1.74,4.40)$ & $2.36(1.28,4.34)$ & $2.31(1.19,4.51)$ & $1.20(0.85,1.70)$ & $1.08(0.74,1.59)$ \\
\hline $\mathrm{UA} \mathrm{pH}<7.20$ & $1.78(1.19,2.66)$ & $1.88(1.23,2.87)$ & $0.85(0.44,1.66)$ & $1.03(0.52,2.04)$ & $0.91(0.67,1.23)$ & $0.93(0.68,1.29)$ \\
\hline $\mathrm{UA} \mathrm{pH}<7.10$ & $3.29(1.82,5.94)$ & $3.35(1.79,6.27)$ & $0.94(0.23,3.88)$ & $1.02(0.24,4.32$ & $1.18(0.65,2.12)$ & $1.26(0.67,2.37)$ \\
\hline Admission to NU & $6.98(4.79,10.16)$ & $6.41(3.84,10.68)$ & $3.73(2.23,6.24)$ & $2.36(1.09,5.10)$ & $1.72(1.33,2.23)$ & $1.90(1.20,3.03)$ \\
\hline
\end{tabular}

${ }^{*}$ Adjusted for maternal age, smoking, nulliparity, previous CS, hypertensive disorder, pre-eclampsia, prematurity, induction and macrosomia

1.15-13.54). Rates of UA $\mathrm{pH}<7.20$ or $<7.10$ in women with $\mathrm{HbA}_{1 \mathrm{c}}$ levels within the range $42-53 \mathrm{mmol} / \mathrm{mol}$ and $\mathrm{HbA}_{1 \mathrm{c}}$ levels $<42 \mathrm{mmol} / \mathrm{mol}$ did not differ significantly.

Higher rates of $\mathrm{NU}$ admission were found in infants of women with type 1 and type 2 diabetes than those in the control group (Table 3). Since the relation between NU admission and prematurity is well-known, subsequent analyses were performed by excluding infants who were born before 37 weeks of gestation. It appeared, the risk for NU admission was more explicit in type 1 and type 2 diabetes (type 1 diabetes $n=43,50 \% \mathrm{NU}$ admission, OR 8.07 CI; 4.75-13.70; type 2 diabetes $n=14$, 35\% NU admission, OR 5.02 CI; 2.31-10.91). Furthermore, the risk of admission to $\mathrm{NU}$ increased significantly, when UA pH decreased (UA $\mathrm{pH}<7.20$, OR $1.32 \mathrm{CI}$; 1.13-1.55; UA $\mathrm{pH},<7.10$ OR $2.63 \mathrm{CI}$; 1.99-3.46; UA $\mathrm{pH}<7.00$, OR 9.07 CI; 4.85-16.95).

\section{Discussion}

\section{Main findings}

In our study, the prevalence of fetal distress as clinical indication for instrumental or cesarean delivery was higher in women with type $1(n=32,27.6 \%)$ and type 2 diabetes $(\mathrm{n}=14,24.1 \%)$ compared to the control group $(n=1655,11.0 \%, p<0.01)$. Furthermore, $\mathrm{UA} \mathrm{pH}$ analysis showed a high prevalence of UA $\mathrm{pH}<7.20 \quad(n=38$, $36.5 \%)$ in infants of mothers with type 1 diabetes compared to the control group $(n=2186,24 . \%, \mathrm{p}<0.01)$. In addition, rates of infants with $\mathrm{UA} \mathrm{pH}<7.10$ in women with type 1 diabetes $(n=13,12.5 \%)$ and the control group $(n=372,4.2 \%)$ were significantly higher $(\mathrm{p}<0.01)$. All results were confirmed by multiple regression analysis, adjusted for confounding factors as age, parity, previous CS, smoking, hypertensive disorder, pre-eclampsia, prematurity, induction of labor and macrosomia. These results suggest that infants of women with type 1 diabetes are at increased risk to suffer from fetal distress during delivery compared to the control group.

A relationship was found between high $\mathrm{HbA}_{1 \mathrm{c}}$ levels and low UA $\mathrm{pH}$. Infants of women with $\mathrm{HbA}_{1 \mathrm{c}}$ levels > $53 \mathrm{mmol} / \mathrm{mol}$ were over 2.5 times more likely for UA
$\mathrm{pH}<7.20$ or $\mathrm{UA} \mathrm{pH}<7.10$ than women with $\mathrm{HbA}_{1 \mathrm{c}}$ levels $<42 \mathrm{mmol} / \mathrm{mol}$, suggesting that poorly regulated diabetes results in higher rates of neonatal asphyxia. Furthermore, lower umbilical artery $\mathrm{pH}$ were significantly associated with higher rates of NU admission. Not unexpectedly, there was a higher prevalence of hypertensive disorders in all diabetic women. Hypertension in pregnancy is a well-known risk factor for perinatal asphyxia [23]. Our results remained unchanged after adjustment for hypertensive disorders.

\section{Strengths and limitations}

Our retrospective case-cohort study covers a period of 10 years, thereby comprising a large population of women with diabetes. Our study is the first that has systematically evaluated perinatal outcomes of women with type 1 , type 2 and gestational diabetes mellitus. The results from comparative analysis were confirmed by multiple regression analysis. In addition, our study was done in a tertiary care hospital. Thereby, the control group consisted of women with low to high risk of perinatal complications. Differences in rates of fetal distress or $\mathrm{UA} \mathrm{pH}$ in women with diabetes mellitus in comparison with low-risk controls may be more explicit.

Our study had some limitations. Hospital-based administrative databases are subject to errors of omission and coding errors. A potential for under-ascertainment and misclassification bias exist. We tried to minimized this risk by double checking the patients charts. The diagnosis of fetal distress was based on the clinical assessment of the gynecologist or midwife. We lacked objective data on CTG analyses, and only in a small number of cases was the decision for instrumental delivery based on low fetal scalp $\mathrm{pH}(<7.20) . \mathrm{HbAl}_{\mathrm{c}}$ levels were used as unit of measure for glucose regulation. It is ambiguous whether $\mathrm{HbAl}_{\mathrm{c}}$ levels are a result from continuously variable or constant glucose levels during pregnancy. Also, we lacked data on glucose regulation prior to delivery. A cohort study performed in a single hospital may limit the capacity to draw conclusions from results, since risk for gestational diabetes or fetal distress 
may differ between populations and obstetrical management of diabetes during pregnancy may differ between hospitals.

\section{Interpretation}

There are other studies that describe the relation between fetal hypoxia and diabetes mellitus. A large population-based study from Lower Saxony in Germany recently reported high rates of $\mathrm{UA} \mathrm{pH}<7.00$ in women with pregestational diabetes compared to controls (OR 2.481). The rate of UA pH 7.00-7.20 was also increased (OR 1.59). However, no distinction was made between type 1 and type 2 diabetes, and no multiple regression analysis was performed [24]. Moreover, in a prospective cohort study by Olofsson et al. [25]. a slightly increased risk for $\mathrm{pH}<7.26$, obtained by fetal scalp blood testing, and UA acidosis was reported in diabetic $(n=46)$ compared to non-diabetic pregnancies $(n=46)$. Also, Reif et al. [26]. confirmed lower UA pH in women with diabetes $(n=57)$ in comparison with the control group $(n=114)$ (7.215 vs. 7.250, $p=0.007$ ). Nevertheless, in both studies, the sample size was too small to distinguish between type 1, type 2 and gestational diabetes. A prospective study comparing UA $\mathrm{pH}$ and nucleated red blood cells in women with diabetes $(n=68)$ and healthy controls $(n$ $=410)$, also showed low UA pH (7.22 vs. 7.24, $p=0.004)$. However, delivery mode differed within both groups and they lacked multiple regression analysis [27]. Klemetti et al. [28] examined the trends in glycaemic control among type 1 diabetic patients and their relation to adverse perinatal outcome. Main result were an increasing trend of $\mathrm{HbA}_{1} \mathrm{C}$ levels prior to delivery and their negative correlation with UA $\mathrm{pH}$. This is in accordance with our results and emphasizes the importance of good glucose regulation .

There are other findings in diabetic pregnancy that support our results. In a study by Teramo et al. [29], it was found that fetal erythropoietin (EPO) concentrations in macrosomic infants of diabetic mothers were elevated. Since tissue hypoxia is the major stimulus of EPO, this also implies a relationship between diabetes and fetal distress. Likewise, EPO levels in the umbilical cord blood are higher after uncomplicated vaginal birth than after elective CS [30]. This is explained by reduced placental perfusion caused by prolonged uterine contractions in combination with maternal bearing down efforts [31]. Since diabetes mellitus is associated with an increased prevalence of vascular diseases, high rates of fetal distress may possibly be explained by vascular changes in the placental circulation, causing reduced placental perfusion. This hypothesis was emphasized by Jones et al., demonstrating reduced placental fractional power Doppler signal in diabetic compared to healthy pregnancies [32].
Several studies have reported abnormal development and functioning of the fetoplacental vascular system, such as increased vascular permeability and increased angiogenesis. [33, 34] Diabetic placentas are often hypertrophied, with possible alterations in branching patterns, villous surface area an villous thickness. [34-36] Calderon et al. [36] reported that the higher the glycemic level, the lower the number of terminal villi, suggesting placenta inadequacy to ensure maternal-fetal exchanges and fetal oxygen delivery.

In cases of acute hypoxia, calcifications, fibrin deposition and fibrosis, due to membrane laminar necrosis and villous infarction, are often observed. [37] A small study of macroscopic placental changes in diabetes mellitus has shown that all women demonstrated some of those changes on the maternal or fetal surface of the placenta. [38] Those findings have their limitations, because they may occur in uncomplicated pregnancies as well. [37] However, this may also indicate that fetuses of women with diabetes may suffer from hypoxia prior to delivery.

\section{Conclusion}

Type 1 and type 2 diabetes are associated with an increased risk of fetal distress during delivery as clinical indication for instrumental or cesarean delivery. Moreover, type 1 diabetes is significantly associated with lower UA pH and higher rates of NU admission. Future studies should examine placental abnormalities in relation to UA pH and NU admission. Also, it should be examined whether a strict glucose regulation during pregnancy reduces the prevalence of placental vascular abnormalities and vasculopathy, and thereby reduces the rates of peripartum hypoxia. Consequently, enhanced information about the relation between glucose regulation, obstetrical management and neonatal outcome can be given to diabetic women prior to labour and delivery.

\section{Abbreviations}

BMI: body mass index; Cl: confidence interval; CS: cesarean section; CTG: cardiotocography; EPO: Erythropoietin; NU: neonatal unit; OR: odd ratio; UA: umbilical artery

\section{Acknowledgements \\ The authors would like to thank A. van Poelgeest for her invaluable assistance in carrying out data entry and $\mathrm{H}$. Ket for his guidance with literature search. The authors would also like to express their gratitude to F. van den Dungen, for his knowledge and information on neonatal admission, and Z.R.G. Chandoe and K.J. Kaland for retrieving information from patient records.}

\section{Availability of data and materials}

The dataset supporting the conclusions of this article is available in the figshare repository, https://doi.org/10.6084/m9.figshare.6262952.v1.

\section{Authors' contributions}

$\mathrm{BC}$ collected data, performed the statistical analyses, interpreted the data and wrote the manuscript. $\mathrm{KH}$ collected data, assisted with data analysis and interpretation, and made contributions to the manuscript. JT directed statistical analyses. JH, RIJ, AV and CG assisted with data analysis and interpretation, and revised the manuscript. MW initiated and supervised the 
research, directed the data analysis and edited the manuscript. All authors read and approved the final version of the manuscript.

\section{Competing interest}

Authors have nothing to disclose. There are no potential conflicts of interest of a financial or other nature.

\section{Ethics approval and consent to participate}

Ethics approval was not required due to the study design (retrospective analysis of patient hospital data, see: http://www.ccmo.nl/nl/ dossieronderzoek?526591f4-32c8-4bcb-82ee-7f21c35ff8ba).

\section{Publisher's Note}

Springer Nature remains neutral with regard to jurisdictional claims in published maps and institutional affiliations.

\section{Author details}

'Department of Obstetrics and Gynecology, VU University Medical Center, PO Box 7057, Amsterdam 1007 MB, the Netherlands. ²Department of Obstetrics and Gynecology, Onze Lieve Vrouwe Gasthuis, Amsterdam, the Netherlands. ${ }^{3}$ Department of Internal Medicine, VU University Medical Center, Amsterdam, the Netherlands. ${ }^{4}$ Department of Epidemiology \& Biostatistics and Department of Health Sciences, VU University, Amsterdam, the Netherlands.

Received: 3 June 2016 Accepted: 1 June 2018

Published online: 14 June 2018

\section{References}

1. American Diabetes Association. Diagnosis and classification of diabetes mellitus (position statement). Diabetes Care. 2009;32(Suppl I):S62-7.

2. National Institute for Health and Clinical Excellence. Diabetes in pregnancy: management of diabetes and its complications from preconception to the postnatal period. London: NICE, 2008.

3. Hartling L, Dryden DM, Guthrie A, et al. Screening and Diagnosing Gestational Diabetes Mellitus. Evidence Report/Technology Assessment No. 210. In: (Prepared by the University of Alberta Evidence-based Practice Center under Contract No. 290-2007-10021-I.) AHRQ Publication No. 12(13)E021-EF. Rockville: Agency for Healthcare Research and Quality; 2012.

4. Moyer VA, U.S. Preventive Services Task Force. Screening for gestational diabetes mellitus: U.S. preventive services task force recommendation statement. Ann Intern Med. 2014;160:414.

5. Lawrence JM, Contreras R, Chen W, Sacks DA. Trends in the prevalence of pre-existing diabetes and gestational diabetes mellitus among a racially/ ethnically diverse population of pregnant women, 1999-2005. Diabetes Care. January 25, 2008;

6. Stichting Perinatale Registratie Nederland Grote Lijnen 1999-2012 Utrecht: Stichting Perinatale Registratie Nederland, 2013.

7. Gaillard R, Durmus B, Hofman A, Mackenbach JP, Steegers EA, Jaddoe WW. Risk factors and outcomes of maternal obesity and excessive weight gain during pregnancy. Obesity. 2013 May;21(5):1046-55. https:// doi.org/10.1002/oby.20088.

8. Wang $Y$, Storlien $L H$, Jenkins $A B$, Tapsell LC, Jin $Y$, Pan JF, et al. Dietary variables and glucose tolerance in pregnancy. Diabetes Care. 2000 Apr; 23(4):460-4

9. Liu J, Laditka JN, Mayer-Davis EJ, Pate RR. Does physical activity during pregnancy reduce the risk of gestational diabetes among previously inactive women? Birth. 2008 Sep;35(3):188-95. https://doi.org/10.1111/j. 1523-536X.2008.00239.X.

10. Evers IM, de Valk HW, Visser GHA. Risk of complications of pregnancy in women with type 1 diabetes. Nationwide prospective study in the Netherlands. BMJ. https://doi.org/10.1136/bmj.38043.583160.EE. (published 5 April 2004)

11. Persson $M$, Normal $M$, Hanson U. Obstetric and perinatal outcomes in type 1 diabetic pregnancies. Diabetes Care. 2009;32 2005-2009

12. Naylor CD, Sermer M, Chen E, Sykora K. Cesarean delivery in relation to birthweight and gestational glucose tolerance: pathophysiology or practice style? JAMA. 1996;275:1165-70.

13. Lai FY, Johnson JA, Dover D, Kaul P. Outcomes of singleton and twin pregnancies complicated by pre-existing diabetes and gestational diabetes: a population-based study in Alberta, Canada, 2005-11. Journal of Diabetes. 2015:8:45-55.

14. Billionnet C, Mitanchez D, Weill A, Nizard J, Alla F, Hartemann A, Jacqueminet $\mathrm{S}$. Gestational diabetes and adverse perinatal outcomes from 716,152 births in France in 2012. Diabetologia. 2017;60:636-44. https://doi. org/10.1007/s00125-017-4206-6.

15. Schmidt MI, Duncan BB, Reichelt AJ, Branchtein L, Matos MC, Costa e Forti A, et al. Gestational diabetes mellitus diagnosed with a 2-h 75-g oral glucose tolerance test and adverse pregnancy outcomes. Diabetes Care. 2001;24:1151-5.

16. Siddiqui F, James D. Fetal monitoring in type 1 diabetic pregnancies. Early Hum Develop. 2003;72:1-13.

17. Diabetes mellitus en zwangerschap. NVOG 2010. Available at https:// richtlijnendatabase.nl/richtlijn/diabetes_en_zwangerschap/startpagina_dm_ en zwangerschap.html Last accessed 5 Jan 2014.

18. Sluiter AC, Van Wijland JJ, Arntzenius AB, Bots AFE, Dijkhorst-Oei LT, Van d. Does FEE, et al. Landelijke Transmurale Afspraak Diabetes mellitus type 2. Huisarts Wet. 2012;55(1):S1-12.

19. Health Organization Department of Noncommunicable Disease Surveillance Definition, diagnosis and classification of diabetes mellitus and its complications. In: Report of a WHO consultation. Part 1: Diagnosis and classification of diabetes mellitus. Geneva, World Health Organization; 1999.

20. Barret JFR, Hannah ME, Hutton EK, Willan AR, Allen AC, Armson A, et al. A randomized trial of planned cesarean or vaginal delivery for twin pregnancy. N Engl J Med. 2013 Oct 3;369(14):1295-305. https://doi.org/10. 1056/NEJMoa1214939.

21. National Institute for Health and Clinical Excellence. Intrapartum care: care of healthy women and their babies during childbirth. London: RCOG Press; 2007.

22. Yeh $\mathrm{P}$, Emary $\mathrm{K}$, Impey $\mathrm{L}$. The relationship between umbilical cord arterial $\mathrm{pH}$ and serious adverse neonatal outcome: analysis of 51519 consecutive validated samples. BJOG. 2012;119(7):824-31.

23. Ferrazzani S, Luciano R, Garofalo S, D'Andrea V, De Carolis S, De Carolis MP, et al. Neonatal outcome in hypertensive disorders of pregnancy. Early Hum Develop. 2011;87:445-9.

24. Günther HH, Scharf A, Hertel H, Hillemanns $P$, Wenzlaff $P$, Maul H. Perinata morbidity in pregnancies of women with preconceptional and gestational diabetes mellitus incomparison with pregnancies of non-diabetic women. Results of the perinatal registry of lower Saxony, Germany. Z Geburtshilfe Neonatol. 2006:210:200-7.

25. Olofsson P, Ingemarsson I, Solum T. Fetal distress during labour in diabetic pregnancy. Br J Obstet Gynaec. 1986;93(10):1067-71.

26. Reif P, Panzitt T, Moser F, Resch B, Haas J, Lang U. Short-term neonatal outcome in diabetic versus non-diabetic pregnancies complicated by non-reassuring foetal heart rate tracings. J Maternal Fetal Neonatal Med. 2013;26:1500-5.

27. Jahromi BN, Ahmadi N, Cohan N, Jahromi MRN. Comparison of the umbilical artery blood gas, nucleated red blood cell, C-reactive protein, and white blood cell differential counts between neonates of diabetic and nondiabetic mothers. Taiwan J Obstet Gynecol. 2011;50:301-5.

28. Klemetti M, Nuutila M, Tikkanen M, Kari MA, Hiilesmaa V, et al. Trends in maternal BMI, glycaemic control and perinatal outcome among type 1 diabetic pregnant women in 1989-2008. Diabetologia. 2012;55:2327-34

29. Teramo K, Kari MA, Eronen M, Markkanen H, Hiilesmaa V. High amniotic fluid erythropoietin levels are associated with an increased frequency of fetal and neonatal morbidity in type 1 diabetic pregnancies. Diabetologia. 2004:47:1695-703.

30. Teramo KA, Widness JA. Increased fetal plasma and amniotic fluid erythropoietin concentrations: markers of intra-uterine hypoxia. Neonatology. 2009;95:105-16.

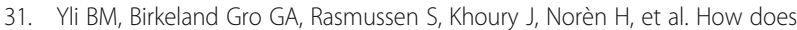
the duration of active pushing in labor affect neonatal outcomes? J Perinat Med. 2012;40:171-8.

32. Jones NW, Deshpande R, Mousa HA, Mansell P, Raine-Fenning N. Fractional volume of placental vessels in women with diabetes using a novel stereological 3D power Doppler technique. Placenta. 2013:34:1002-8.

33. Jauniaux E, Burton GJ. Villous histomorphometry and placental bed biopsy investigation in type 1 diabetic pregnancies. Placenta. 2006:27:468-74.

34. Leach L, Taylorm A, Sciota F. Vascular dysfunction in the diabetic placenta: causes and consequences. J Anat. 2009:215:69-76.

35. Jirkovská M, Kučera T, Kaláb J, Jadrníček M, Niedobová V, Janáček J, et al. The branching pattern of villous capillaries and structural changes of placental terminal villi in type 1 diabetes mellitus. Placenta. 2012;33:343-51. 
36. Calderon IMP, Damasceno DC, AMorin RL, Costa RAA, Brasil MAM, Rudge MVC. Morphometric study of placental villi and vessels in women with mild hyperglycemia or gestational or overt diabetes. Diabetes Res Clin Pract. 2007:78:65-71.

37. Stanek J. Hypoxic patterns of placental injury. Arch Pathol Lab Med. 2013; 137:706-20.

38. Marques Salge AK, Nunes Rocha KM, Xavier RM, Ramalho WS, Rocha ÉL, Guimarães JV, et al. Macroscopic placental changes associated with fetal and maternal events in diabetes mellitus. CLINICS. 2012;67:1203-8.

Ready to submit your research? Choose BMC and benefit from:

- fast, convenient online submission

- thorough peer review by experienced researchers in your field

- rapid publication on acceptance

- support for research data, including large and complex data types

- gold Open Access which fosters wider collaboration and increased citations

- maximum visibility for your research: over $100 \mathrm{M}$ website views per year 